\title{
Medical Mythology: an introduction to a new section
}

\author{
Garth Dickinson, MD
}

See also page 120.

$I^{\mathrm{t}}$ you don't remember the loading dose of aminophylline for treating acute asthmatics, then you are younger than I. The constant infusion rate then had to be carefully altered, depending on the smoking status of the patient. This was important stuff when I was a medical student. Failure to know risked failure to pass. Today this subject is irrelevant, but not too long ago it was dogma. Aminophylline therapy for acute asthma has moved from standard of care to medical myth to historic curiosity.

Mythology is defined as a popular belief or assumption that has grown up around someone or something. In the world of medicine, before the advent of the randomized clinical trial and evidence-based medicine, the standards were set by "expert opinion." The experts were the distinguished professors who wrote "the gospel" and frequently published it in their own textbooks. There was a lot of brilliant observation in these tomes, which has formed the basis for modern clinical practice and teaching. Interspersed and rarely differentiated was a lot of unsubstantiated crap, which has formed the basis of medical mythology.

A myth is defined as something having only an imaginary or unverifiable existence. Medical mythology has deep roots: trephining the skull to release harmful vapours, bleeding or leeches to treat just about everything, and arsenic to cure syphilis. Modern medical mythology continues to thrive. Remember the hype about high dose epinephrine? We needed large, expensive clinical trials to refute the multiple case reports and testimonials that highdose epi was the key to eternal life. Do you still withhold analgesia until the surgeon has palpated that ruptured appendix, order a serum osmolality to rule out methanol intoxication, patch corneal abrasions, order skull films, and adhere to the brain-dead ATLS philosophy of universal ordering of C-spine radiography? Where will t-PA for stroke settle 10 or 15 years from now? Fifty years from now they'll probably be laughing at the dweebs from the turn of the century who followed the 4-step Ottawa Ankle Rules instead of the modern Kuala Lumpur 3-step Ankle Rules (injured leg first).

Mythology is a component of medical progress. We learn more and reject the old only to learn more still and reject what once was new. Exploring this process of change is exciting and humbling. How much of what we do now is beneficial to our patients and how much is simply complying with our preconceived assumptions and benefiting no one? We always strive to do the best we can with the best information available. In the modern practice of medicine it is astounding how often the quality of the best information is poor.

In this issue of CJEM we commence a new section on medical mythology. Our host and editor will be Dr. Mel Herbert, an Associate Professor from the University of Southern California. Mel is originally from $\mathrm{Oz}$ (tralia), but when he clicked his ruby red slippers together he caught a heel, missed Kansas and landed in LA. He did his EM training at UCLA and now works in the emergency departments of LA County Hospital and USC Medical Center. $\mathrm{He}$ has distinguished himself with teaching and education awards from Cal ACEP and UCLA. He launched EMRAP, a monthly educational EM audio series, and has recently filled in on the EMA audio series while Jerry Hoffman is off in Japan checking out silk kimonos.

The subject of the hallowed pelvic exam is the first topic in this series. Do women really have palpable ovaries?

Competing interests: None declared.

Correspondence to: Dr. Garth Dickinson; garth.dickinson@ rogers.com 